\title{
Isolation and Screening of Lignolytic Fungi from Various Ecological Niches
}

\author{
Anuja Sharma ${ }^{1, *}$, Neeraj K. Aggarwal ${ }^{1}$, AnitaYadav ${ }^{2}$ \\ ${ }^{1}$ Department of Microbiology, Kurukshetra University, Kurukshetra, India \\ ${ }^{2}$ Department of Biotechnology, Kurukshetra University, Kurukshetra, India
}

Copyright $\mathrm{O} 2017$ by authors, all rights reserved. Authors agree that this article remains permanently open access under the terms of the Creative Commons Attribution License 4.0 International License

\begin{abstract}
Lignin is a major noncarbohydrate polyphenolic structural constituent of cell wall of all the vascular plants and is present in association with cellulose and hemicellulose. It is the second most abundant polymer after cellulose. Lignin is well known for its resistance to microbial degradation because of its high molecular weight and various biologically stable carbon-carbon and ether linkages. Seventy two fungal isolates capable of utilizing lignocellulosic biomass were isolated from different ecological samples. When subjected to primary screening by qualitative plate assay method using methyl orange, azure B, guaiacol and tannic acid as indicators for determining the lignolytic potential, 22 isolates were found positive for at least one of the indicators. Six isolates were found to exhibit all the three extracellular enzyme activities on quantitative estimation of laccase, manganese peroxidase and lignin peroxidase activities. Highest laccase activity was produced by ANF238 (3.42U/ml) while highest manganese peroxidase and lignin peroxidase activities were produced by ANF 212 $(0.254 \mathrm{U} / \mathrm{ml})$ and ANF238 $(0.22 \mathrm{U} / \mathrm{ml})$ respectively.
\end{abstract}

Keywords Dye Decolorization, Laccase, Lignin, Lignin Peroxidase, Manganese Peroxidase

\section{Introduction}

Industrial development and enormous use of fossil fuels has led to the deterioration of our natural environment and thus awareness for the search of alternative clean and renewable energy sources is required [1]. Biofuels are an attractive alternative for this, ensuring energy security and the advantage of greatly minimized loss to the environment compared to that caused by fossil fuels. Lignocellulosic biomass is a cheap, renewable, abundant resource which can be exploited for the production of biofuel. Lignocellulosic biomass is composed of three main constituents: cellulose, lignin and hemicellulose. Lignin is a major noncarbohydrate polyphenolic structural constituent of cell wall of all the vascular plants which keeps cellulose and hemicelluloses polymers locked within the structural confinements of cell wall. It is the second most abundant polymer after cellulose $[2,3,4]$. Lignin is well known for its resistance to enzymatic degradation by microorganisms due to extensive crosslinking between its polyphenolic constituents and biologically stable ether linkages $[4,5]$.

Lignocellulosic biomass as a substrate for bioethanol production presents a number of challenges [6]. A pretreatment step is required to make cellulose and hemicellulose portions of the biomass available for their breakdown into sugars for the saccharification and fermentation steps to be carried out in an efficient and cost effective manner. Low efficiency is the major challenge at this step due to the natural recalcitrance of lignocellulose to degradation and high cost of enzymatic conversion [7,8]. Pretreatment is therefore the most essential step required to prepare cellulose and hemicellulose for enzymatic hydrolysis with high yield [9]. A wide range of physical and chemical methods and combinations are employed for pretreatment of lignocelluloses. However, these methods have associated disadvantages such as high energy consumption during treatment, high cost of equipment use of costly chemicals increasing cost of treatment and loss of sugars during chemical treatment, etc. $[10,11]$.

Recently, the environment friendly and cost effective approach of microbial pretreatment has received attention of researchers for enhancing enzymatic saccharification of lignocellulosic biomass. This method employs micro-organisms, mainly white and soft rot fungi, actinomycetes, and bacteria which degrade lignin, the most recalcitrant polymer in biomass through the action of lignin degrading enzymes. Two families of lignolytic enzymes play the major role in the enzymatic degradation of lignin: phenol oxidase (laccase) and peroxidises (lignin peroxidase, LiP and manganese peroxidase, $\mathrm{MnP}$ ) [12]. Extensive research has been done to study the potential of microorganisms to degrade lignin and has shown that white rot fungi are the most efficient lignin degraders [13]. Thus most of the research concerning production of lignolytic enzymes and 
biodegradation of lignin has been centred on white rot fungus and brown rot fungus.

Conventional production of lignolytic enzymes is done using substrates like phenolic compounds thus making these methods costly and unsafe. An alternative to these substrates is the cheap, renewable, economically feasible and abundantly available lignocellulosic biomass [14, 15]. Conventional lignocellulosic sources includes agro-industrial residues, dedicated herbaceous, hardwoods and softwoods and forest residues while non-conventional sources include industrial cellulosic waste, municipal solid waste and weeds. Out of these, weeds are an attractive lignocellulosic source for enzyme production. One such weed is Eichhornia crassipes commonly known as Water hyacinth. Eichhornia crassipes, a native of South America is one of the world's worst invasive weeds due to its rapid growth rate, and impact on environment, ecological communities, human health and socioeconomic development. Strategies including physical removal, chemical methods and biological control agents have proven inefficient for complete eradication of Eichhornia crassipes because of various environmental and financial factors associated with these methods. On the other hand, water hyacinth, due to its low lignin and high holocellulose content is a rich source of lignocellulosic biomass and has demonstrated abilities to be used as a raw material in various useful applications and thus its management by large scale utilization provides an attractive approach [16]. Water hyacinth being an aquatic plant does not compete with land resources. Also, high biomass productivities and abundance of this plant offers another advantage. The present study was initiated with the aim of isolation and screening of potential lignolytic fungi from various environmental sources.

\section{Materials and Methods}

\subsection{Collection of Samples for Isolation of Lignolytic Organisms}

Soil samples were collected from various agricultural (which is used for cultivation of major crops including rice, wheat, sugarcane, and cotton) and non-agricultural lands in Kurukshetra, Ambala and nearby regions. Besides this rotten wood and fruit samples, compost, termite infested wood, Cardboard industry waste water were also used for isolation of lignolytic fungi.

\subsection{Lignocellulosic biomass}

Water hyacinth was collected from local ponds in Kurukshetra. Only shoots and leafy parts of the plant were used to prepare biomass. It was washed, chopped in to small pieces $(1-2 \mathrm{~cm})$, dried at $70^{\circ} \mathrm{C}$ till constant weight and was ground into fine powder and sieved to obtained biomass of different mesh size. Biomass of particle size 0.3-0.4 mm was used for screening and production of lignolytic enzymes.

\subsection{Isolation of Lignolytic Fungi}

Isolation was done using enrichment culture technique. For enrichment $1 \mathrm{~g}$ of sample was suspended in $50 \mathrm{ml}$ of basal medium [17] containing $1 \%$ water hyacinth biomass as the sole carbon source and incubated at $25^{\circ} \mathrm{C}$ at $130 \mathrm{rpm}$ for 7 days. After 4-5 transfers in fresh medium, serial dilutions were prepared in normal saline solutions $(0.85 \% \mathrm{NaCl})$ and plated on agar plates with same composition as enrichment medium. Pure fungal cultures were obtained by subsequent transfers to fresh lignin agar (basal medium with $0.1 \%$ lignin) plates.

\subsection{Primary Screening}

Primary screening of isolates for their lignolytic potential was done by qualitative plate assay using methyl orange, azure B, guaiacol, tannic acid as indicators for lignolytic potential:

\subsubsection{Methyl Orange Dye Decolorization Plate Assay}

Culture was inoculated onto methyl orange agar plates $\left(0.5 \%\right.$ methyl orange in PDA) and incubated at $25^{\circ} \mathrm{C}$. Growth was followed for a period of 2 weeks. Positive reaction is indicated by the formation of a clear zone around the colony. Positive results indicate the production of lignin degrading enzymes which decolorize the polymeric dyes.

\subsubsection{Guaiacol Plate Assay}

Culture was inoculated onto guaiacol agar plates $(.01 \%$ guaiacol in CDA) and incubated at $25^{\circ} \mathrm{C}$. Growth was followed for a period of 2 weeks. Positive reaction is indicated by the formation of a brown zone around the colony. Positive results indicate the production of laccase enzyme which oxidizes guaiacol.

\subsubsection{Azure B Dye Decolorization Plate Assay}

Culture was inoculated onto azure B agar plates containing $.01 \%$ azure B [18] and incubated at $25^{\circ} \mathrm{C}$. Growth was followed for a period of 2 weeks. Positive reaction is indicated by the formation of a clear zone around the colony. Positive results indicate the production of lignin peroxidase enzyme which decolorizes Azure B.

\subsubsection{Tannic Acid Plate Assay}

Culture was inoculated onto tannic acid agar plates containing $0.2 \%$ tannic acid and incubated at $25^{\circ} \mathrm{C}$. Growth was followed for a period of 2 weeks. Positive reaction is indicated by the formation of a yellow to light brown zone around the colony. Positive results indicate the production of laccase enzyme which oxidizes tannic acid [19].

\subsection{Secondary Screening}

Quantitative assay was done to determine the potential of 
selected isolates to degrade lignin present in water hyacinth biomass by following the activity of various extracellular lignolytic enzymes including laccase, lignin peroxidase and manganese peroxidase. $50 \mathrm{ml}$ of basal medium was taken in $250 \mathrm{ml}$ Erlenmeyer flasks and supplemented with $1 \%$ water hyacinth biomass. Inoculation was done with one $8 \mathrm{~mm}$ disc of pure fungal culture, incubated at $25^{\circ} \mathrm{C}$. Sample was withdrawn at two days intervals, after which the culture was filtered through muslin cloth and centrifuged at $10,000 \times \mathrm{g}$ for 30 mins at $4{ }^{\circ} \mathrm{C}$. The supernatant was filtered through Whatman no. 1 filter paper and lignin degradation was followed by measuring the activity of various extracellular enzymes in the crude enzyme extract.

\subsection{Enzyme Production}

\subsubsection{Stationary Conditions}

Enzyme production was observed under static flask culture conditions using $1 \%$ water hyacinth biomass in basal medium. Enzyme production was done in $250 \mathrm{ml}$ Erlenmeyer flasks containing $50 \mathrm{ml}$ of the culture media. Initial $\mathrm{pH}$ of the medium was set at 5.0. The media was inoculated with one $8 \mathrm{~mm}$ disc and incubated at $25 \pm 2{ }^{\circ} \mathrm{C}$ for 10 days. For crude enzyme preparation culture was filtered through muslin cloth and centrifuged at $10,000 \times \mathrm{g}$ for $30 \mathrm{~min}$ at $4^{\circ} \mathrm{C}$. The supernatant was filtered through Whatman no. 1 filter paper and assayed for laccase, lignin peroxidase and manganese peroxidase enzyme activity.

\subsubsection{Solid State Fermentation}

Enzyme production was observed under solid state fermentation in $50 \mathrm{ml}$ Erlenmeyer flasks containing $5 \mathrm{~g}$ water hyacinth biomass. $10 \mathrm{ml}$ Basal medium was used to attain $200 \%$ initial moisture level. Initial $\mathrm{pH}$ of the medium was set at 5.0. The media was inoculated with one $8 \mathrm{~mm}$ disc and incubated at $25 \pm 2^{\circ} \mathrm{C}$ for 10 days. For crude enzyme extraction $10 \mathrm{ml}$ of $0.5 \mathrm{M}$ acetate buffer $(\mathrm{pH}=5.0)$ was added, after which the culture was filtered through muslin cloth and centrifuged at $10,000 \times \mathrm{g}$ for $30 \mathrm{~min}$ at $4^{\circ} \mathrm{C}$. The supernatant was filtered through Whatman no. 1 filter paper and assayed for laccase, lignin peroxidase and manganese peroxidase enzyme activity.

\subsection{Enzyme Assay}

Laccase

The laccase activity was determined using Guaiacol $(2 \mathrm{mM})$ in sodium acetate buffer (10mM pH 5.0) as a substrate [20]. The reaction mixture contained $1.5 \mathrm{ml}$ acetate buffer, $0.5 \mathrm{ml}$ guaiacol and $0.5 \mathrm{ml}$ enzyme extract. The mixture was incubated at $30^{\circ} \mathrm{C}$ for 30 minutes and absorbance taken at $450 \mathrm{~nm}$ using Systronics UV- visible double beam spectrophotometer 2205. The intense brown colour development due to oxidation of guaiacol by laccase is correlated to its activity read at $450 \mathrm{~nm}$. 1 Unit of enzyme activity is defined as the amount of enzyme required to oxidize $1 \mu \mathrm{m}$ of guaiacol per minute. The laccase activity in $\mathrm{U} / \mathrm{ml}$ is calculated using the extinction coefficient of guaiacol $\left(12,100 \mathrm{M}^{-1} \mathrm{~cm}^{-1}\right)$ at $450 \mathrm{~nm}$ by the formula:

$$
\text { E. } A=(A * V) /(t * \varepsilon * v)
$$

where E. $\mathrm{A}=$ Enzyme Activity $(\mathrm{U} / \mathrm{ml}), \mathrm{A}=$ Absorbance at $450 \mathrm{~nm}, \mathrm{~V}=$ Total volume of reaction mixture $(\mathrm{ml}), \mathrm{v}=$ enzyme volume $(\mathrm{ml}), \mathrm{t}=$ Incubation time $(\mathrm{min})$ and $\varepsilon=$ Extinction Coefficient $\left(\mathrm{M}^{-1} \mathrm{~cm}^{-1}\right)$.

\section{Manganese Peroxidase}

Manganese peroxidase (MnP) activity was measured following the method described by Paszczynski and coworkers [21]. This method is based on the oxidation of guaiacol. The reaction mixture $(500 \mu \mathrm{l})$ contained $100 \mu \mathrm{l}$ of sodium tartrate buffer (final concentration $0.1 \mathrm{M}, \mathrm{pH} 5.0$ at $30^{\circ} \mathrm{C}$ ), $10 \mu \mathrm{l}$ of guaiacol (final concentration $0.2 \mathrm{mM}$ ), $10 \mu \mathrm{l}$ of $\mathrm{MnSO}_{4}$ (final concentration $0.2 \mathrm{mM}$ ), $100 \mu \mathrm{l}$ of culture supernatant and final volume was made $490 \mu \mathrm{l}$ with distilled water. The reaction was initiated by the addition of $10 \mu \mathrm{l}$ of $\mathrm{H}_{2} \mathrm{O}_{2}$ (final concentration $0.2 \mathrm{mM}$ ) and increase in absorbance due to oxidation of guaiacol was measured at 465 $\mathrm{nm}$ with extinction coefficient, $\varepsilon=12100 \mathrm{M}^{-1} \mathrm{~cm}^{-1}$. Enzyme activity of manganese peroxidase is calculated by the following formula:

$$
1 \text { Unit }=\sim \mathrm{E} / \sim \mathrm{t} * \mathrm{~V} / \mathcal{E} * \mathrm{~V} * \mathrm{t}
$$

where $\sim E / \sim t=$ Increase in absorbance per minute, $V=$ Volume of assay solution in the cuvette, $\varepsilon=$ Extinction coefficient, $\mathrm{v}=$ Volume of sample, $\mathrm{t}=$ time in minutes

One unit enzymatic activity (MnP) was defined as the quantity of enzyme that produced $1 \mu \mathrm{mol}$ of oxidized product per minute at standard conditions.

\section{Lignin Peroxidase}

Lignin peroxidase activity was determined by the method described by Arachibald [22]. This method is based on the oxidation of dye azure $B$. The reaction mixture $(1 \mathrm{ml})$ contained $50 \mathrm{mM}$ sodium tartrate buffer $(\mathrm{pH} 3.0), 32 \mathrm{mM}$ azure $\mathrm{B}, 1 \mathrm{mM}$ hydrogen peroxide and culture filtrate. The mixture is incubated for $10 \mathrm{~min}$ at $30^{\circ} \mathrm{C}$. The reaction was initiated by adding hydrogen peroxide and absorbance is immediately measured at $651 \mathrm{~nm}$ in one-minute intervals after addition of $\mathrm{H}_{2} \mathrm{O}_{2}$. One unit of enzyme activity is expressed as decrease in absorbance of 0.1 units per minute.

\section{Results and Discussions}

\subsection{Isolation}

Soil samples, rotten wood and fruit samples, compost, termite infested wood, cardboard industry waste water were collected from different geographical areas for the isolation of potential lignolytic enzyme producing fungal strains. Enrichment technique was used for the isolation of lignolytic 
fungi as it is known to improve the yield of microorganisms. $1 \%$ dried water hyacinth biomass was used as a lignocellulosic substrate and the only carbon source in the enrichment medium. It is assumed that lignocellulosic materials, such as agricultural by-products or wastes, contain significant concentration of soluble inducers enhancing production of lignocellulose degrading enzymes [23, 24]. In a study conducted on the process for isolation and acclimatization of microorganisms for lignin degradation, enrichment method was used for a better yield of lignolytic organisms [4]. A total of 72 fungal isolates were obtained during our study. These isolates showed their ability to utilize lignin as a carbon source as they could grow on a medium containing lignin as the sole carbon source. Extensive research has been done to isolate lignin degrading organisms by using medium containing lignin as the sole carbon source and to study the enzymes involved in its degradation $[25,26]$.

\subsection{Primary Screening}

Primary screening was done by qualitative plate assay method using methyl orange, azure $\mathrm{B}$, guaiacol and tannic acid as indicators for determining the lignolytic potential. Table 1 represents the source of isolation and status of fungal isolates positive for at least one of the indicators. Use of these dyes and indicators using plate assay is preferred during primary screening as it is easy and quick due to the visible change of colour directly on plates, no measurement of enzyme activity by spectrophotometric method is required thus making the selection process of potent lignolytic enzyme producers out of large number of isolates fast [27, 28].

Table 1. Status of various isolates on different indicators for lignolytic potential

\begin{tabular}{|c|c|c|c|c|c|}
\hline \multirow{2}{*}{$\begin{array}{l}\text { Name of } \\
\text { Isolate }\end{array}$} & \multirow{2}{*}{ Source } & \multicolumn{4}{|c|}{ Name of the indicator } \\
\hline & & $\begin{array}{l}\text { Methyl } \\
\text { Orange }\end{array}$ & Azure B & Guaiacol & Tannic Acid \\
\hline ANF34 & Agricultural soil 2 & + & - & - & - \\
\hline ANF36 & Cardboard industry waste water & + & + & + & - \\
\hline ANF54 & Non Agricultural soil 7 & + & - & - & - \\
\hline ANF55 & Compost & + & - & - & - \\
\hline ANF89 & Agricultural soil 5 & + & - & - & - \\
\hline ANF117 & Rotten fruit & + & - & - & - \\
\hline ANF133 & Non Agricultural soil 8 & + & - & - & - \\
\hline ANF134 & Rotten wood 1 & + & - & - & - \\
\hline ANF184 & Agricultural soil 6 & + & - & - & - \\
\hline ANF185 & Termite infested soil & + & + & - & - \\
\hline ANF188 & Cardboard industry waste water & + & - & - & + \\
\hline ANF203 & Termite infested wood & + & - & - & - \\
\hline ANF212 & Agricultural soil 10 & + & + & + & + \\
\hline ANF213 & Compost & + & - & - & - \\
\hline ANF214 & Non Agricultural soil 10 & + & - & - & - \\
\hline ANF216 & Agricultural soil 11 & + & - & - & - \\
\hline ANF218 & Rotten wood 3 & + & - & + & - \\
\hline ANF222 & Agricultural soil 12 & + & + & - & + \\
\hline ANF223 & Compost & + & - & - & - \\
\hline ANF230 & Non Agricultural soil 11 & + & - & - & - \\
\hline ANF237 & Non Agricultural soil 15 & + & - & - & - \\
\hline ANF238 & Rotten wood 4 & + & + & + & + \\
\hline
\end{tabular}

The fungal isolates were grown on their respective agar plates containing indicator at $25 \pm 20^{\circ} \mathrm{C}$

$+=$ Positive for lignolytic potential

- = Negative for lignolytic potential 


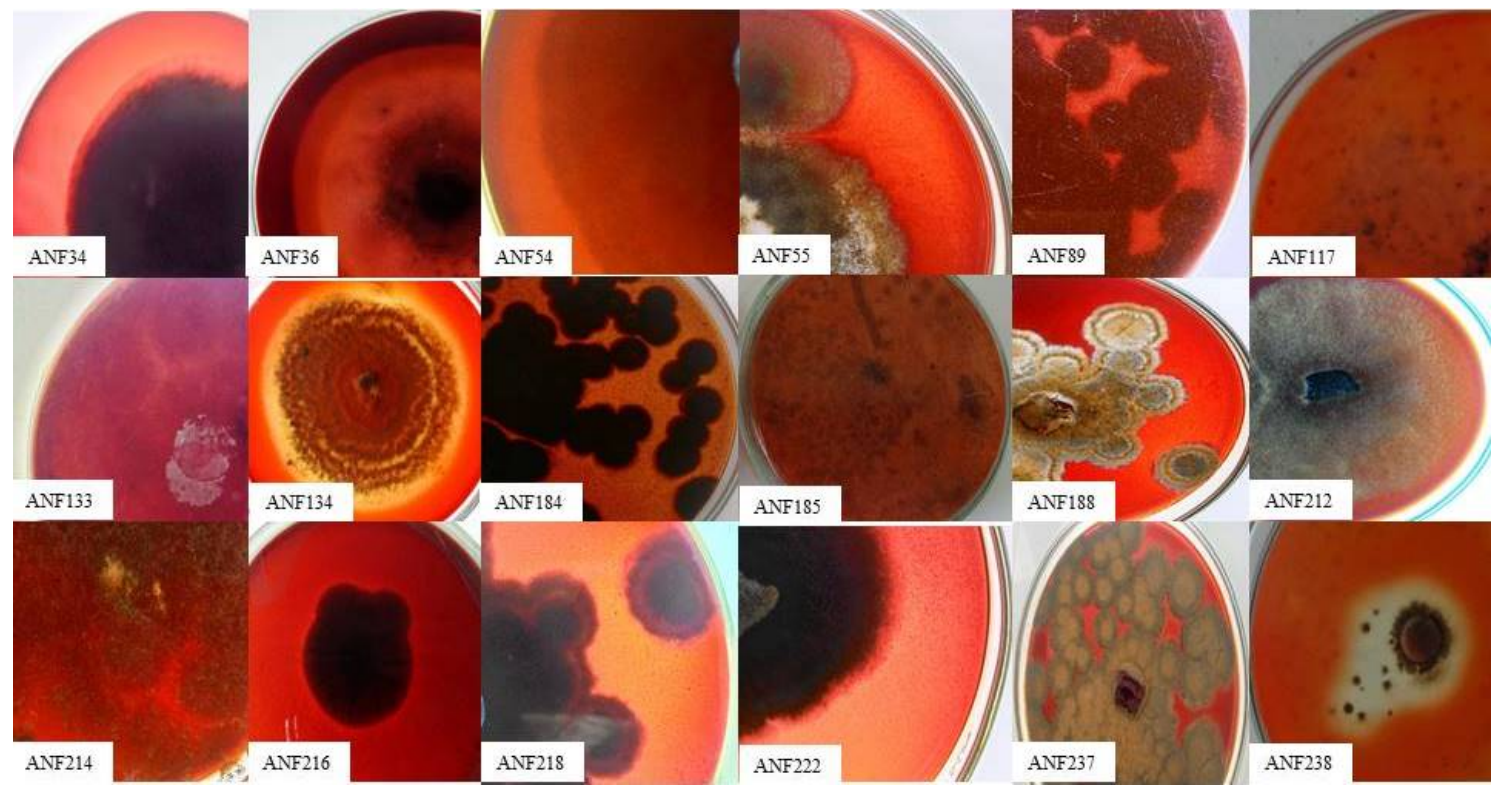

Figure 1. Methyl orange dye decolorization plate assay: Clear zone of decolorization around fungal colony

\subsubsection{Methyl Orange Dye Decolorization Plate Assay (Fig.}

22 fungal isolates (ANF34, ANF36, ANF54, ANF55, ANF89, ANF117, ANF133, ANF134, ANF184, ANF185, ANF188, ANF203, ANF212, ANF213, ANF214, ANF216, ANF218, ANF222, ANF223, ANF230, ANF237, and ANF238) produced a clear zone and thus were found to degrade methyl orange and have lignolytic potential. Lignolytic enzymes like laccase and lignin peroxidase are known to play a significant role in the decolorization of methyl orange. Thus decolorization of methyl orange dye using a plate assay method is used in primary screening of lignolytic microorganisms [29, 30]

\subsubsection{Azure B Dye Decolorization Plate Assay (Fig. 2)}

Only five fungal isolate (ANF36, ANF185, ANF212, ANF222 and ANF238) produced a clear zone and thus was found to degrade azure B. Both azure B and veratryl alcohol are substrates of lignin peroxidase enzyme [31] but azure B has advantage over veratryl alcohol as the action of lignin peroxidase on azure B leads to a visible change in colour by decolourization of azure B from blue to colourless. This feature has been exploited for isolation and screening of lignin peroxidase producing fungi $[32,33]$.

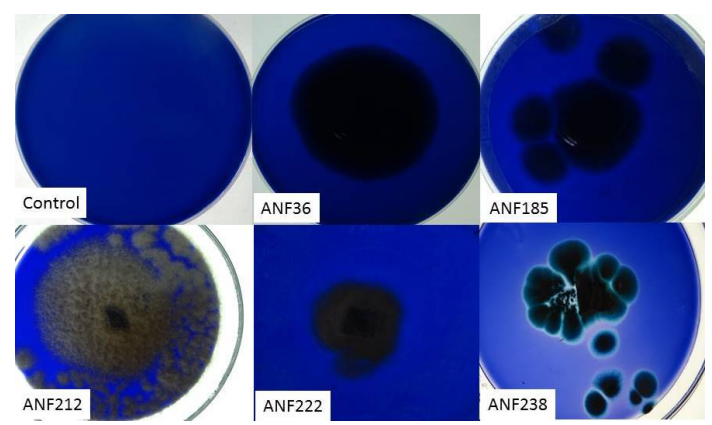

Figure 2. Azure B dye decolorization plate assay: Clear zone of decolorization around fungal colony

\subsubsection{Guaiacol Plate Assay (Fig. 3)}

Four fungal isolate (ANF36 ANF212, ANF218 and ANF238) produced brown coloration around their colony and were positive for guaiacol plate assay. Guaiacol is one of the most commonly used substrate for both qualitative and quantitative determination of laccase [34, 35]. Laccase activity of $A$. flavus in the form of reddish brown coloration around colony was visualized on plates containing G.A.E. (Glucose Asparagine) agar medium supplemented with $0.02 \%$ guaiacol [36]. In plate assays, conducted at optimum growth conditions, both $A$. alternata and $L$. theobromae developed reddish brown color around the colony indicating the production of laccase [35]. Monssef and his coworkers used PDA supplemented with $0.04 \%$ guaiacol for screening of laccase producing fungi and isolated a potent laccase producer Trichoderma harzianum [37]. Production of reddish brown colour is due to the oxidative polymerization of guaiacol in the presence of extracellular fungal laccase [38].

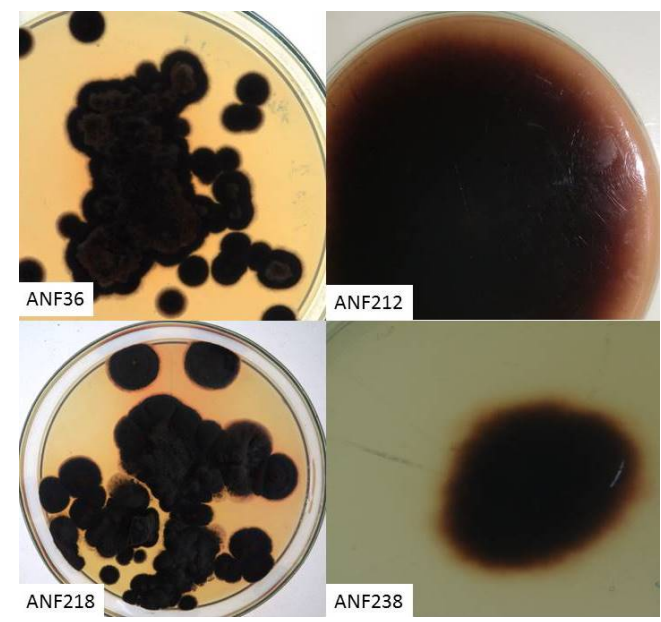

Figure 3. Guaiacol plate assay: Reddish brown colouration around fungal colony 


\subsubsection{Tannic Acid Plate Assay (Fig. 4)}

Four fungal isolates ANF188, ANF 212, ANF 222, and ANF238 produced dark yellow to brown coloration around the fungal colony and was positive for tannic acid plate assay [20]. Geetanjali isolated Chaetomium sp., Penicillium sp., Aspergillus sp. and Trichoderma sp. from forest litter using tannic acid agar plate assay. These fungal strains were found to have lignolytic potential and could degrade areca and coffee husk effectively [39].

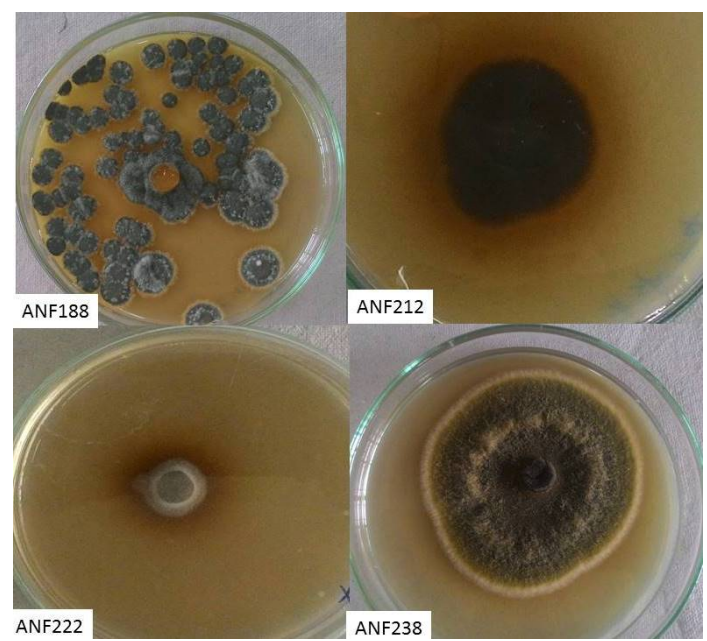

Figure 4. Tannic acid plate assay: Yellow to brown colouration around fungal colony

\subsection{Secondary Screening}

Selected isolates after the primary screening were further assayed for their ability to grow on water hyacinth biomass and to degrade lignin present in water hyacinth biomass. Lignin degradation was followed by measuring the activity of laccase, lignin peroxidase and manganese peroxidase enzymes in the crude enzyme extract (Table 2). All the 22 fungal isolates tested during secondary screening (ANF34, ANF36, ANF54, ANF55, ANF89, ANF117, ANF133, ANF134, ANF184, ANF185, ANF188, ANF203, ANF212, ANF213, ANF214, ANF216, ANF218, ANF222, ANF223, ANF230, ANF237, and ANF238) were capable of producing laccase enzyme. Laccase activity ranged from a minimum of $5.60 \mathrm{U} / \mathrm{ml}$ by ANF 188 to a maximum of $17.13 \mathrm{U} / \mathrm{ml}$ by ANF238. 10 fungal isolates (ANF36, ANF185, ANF212, ANF214, ANF216, ANF218, ANF222, ANF223, ANF237, and ANF238) out of 22 showed MnP activity ranging from $.04 \mathrm{U} / \mathrm{ml}$ to $.254 \mathrm{U} / \mathrm{ml}$. Maximum $\mathrm{MnP}$ activity was produced by ANF212. LiP activity was observed in only six isolates (ANF36, ANF185, ANF212, ANF216, ANF222, and ANF238). LiP activity of these isolates ranged from 0.09 to $0.22 \mathrm{U} / \mathrm{ml}$ with highest being produced by ANF238. Though primary screening using indicators is a major tool for selection of lignolytic organisms, it was observed that there was no direct correlation between enzyme activity and intensity of zone or colouration.

Table 2. Laccase, Lignin peroxidase and Manganese peroxidase enzyme activity of various isolates

\begin{tabular}{|c|c|c|c|c|c|c|c|}
\hline Name of isolate & $\begin{array}{c}\text { Laccase activity } \\
(\mathrm{U} / \mathrm{ml})\end{array}$ & $\begin{array}{c}\text { Lip } \\
\text { Activity } \\
(\mathrm{U} / \mathrm{ml})\end{array}$ & $\begin{array}{l}\text { MnP activity } \\
(\mathrm{U} / \mathrm{ml})\end{array}$ & $\begin{array}{c}\text { Name of } \\
\text { isolate }\end{array}$ & $\begin{array}{l}\text { Laccase activity } \\
(\mathrm{U} / \mathrm{ml})\end{array}$ & $\begin{array}{c}\text { LiP } \\
\text { Activity } \\
(\mathrm{U} / \mathrm{ml})\end{array}$ & $\begin{array}{l}\text { MnP activity } \\
(\mathrm{U} / \mathrm{ml})\end{array}$ \\
\hline ANF34 & 1.93 & 0 & 0 & ANF203 & 1.54 & 0 & 0 \\
\hline ANF36 & 2.67 & .15 & .186 & ANF212 & 2.51 & .19 & .254 \\
\hline ANF54 & 1.88 & 0 & 0 & ANF213 & 1.53 & 0 & 0 \\
\hline ANF55 & 2.21 & 0 & 0 & ANF214 & 1.65 & 0 & .04 \\
\hline ANF89 & 1.35 & 0 & 0 & ANF216 & 1.69 & .09 & .053 \\
\hline ANF117 & 1.28 & 0 & 0 & ANF218 & 2.66 & 0 & .04 \\
\hline ANF133 & 1.23 & 0 & 0 & ANF222 & 1.34 & .18 & .04 \\
\hline ANF134 & 2.17 & 0 & 0 & ANF223 & 2.54 & 0 & .06 \\
\hline ANF184 & 2.05 & 0 & 0 & ANF230 & 1.47 & 0 & 0 \\
\hline ANF185 & 2.66 & .02 & .169 & ANF237 & 2.39 & 0 & .06 \\
\hline ANF188 & 1.12 & 0 & 0 & ANF238 & 3.42 & .22 & .229 \\
\hline
\end{tabular}


The fungal isolates were grown in Basal medium ( $\mathrm{pH}$ 5.0) containing $1 \%$ water hyacinth biomass under stationary conditions of growth at $25 \pm 2^{\circ} \mathrm{C}$.

Out of these, 6 fungal isolates exhibited all three extracellular enzyme activities (highlighted in blue) and four isolates with higher activities were selected for further studies. The extracellular lignolytic enzyme activities of all the four selected fungal isolates during both stationary and solid state fermentation are given in table 3. Results indicated that all the four isolates could efficiently grow and produce lignolytic enzymes in both stationary and solid state conditions of growth and thus could be exploited for enzyme production by stationary as well as solid state fermentation. The selected isolates were initially identified on the basis of their morphological and other cultural characteristics. Further identification was done using microscopic observation after lactophenol cotton blue staining. Features like conidia and their shape and arrangements, conidiophore, hyphae were observed and isolates were classified into different genus on the basis of these features. ANF36, ANF185, ANF212, ANF238 were identified as Penicillium sp., Aspergillus sp., Fusarium sp. and Alternaria sp. Respectively. The organism will be genetically characterized using 28S rDNA based molecular methods. Colony morphology and microscopic view of these isolates are given in figure 5 and 6 . Many other studies have also reported the lignolytic potential of organisms belonging to these genera isolated from various ecological niches. Penicillium was reported to produce ligninolytic enzymes [40]. Low levels of $\mathrm{MnP}$ in certain isolates of Fusarium solani have also been observed [41] though its degrading mechanism is considered to be different from that of the white-rot fungi. $\mathrm{MnP}$ production by Aspergillus terreus has also been reported [42]. Laccase production by two strains of Aspergillus has been reported [43] which were further used for treatment effluent from a nitrocellulose industry. Sahoo and Gupta reported the decolorization of pulp and paper mill effluent by Aspergillus fumigatus capable of producing laccase, $\mathrm{MnP}$ and xylanase [44]. MnP Activity was reported in Alternaria alternata with a possible role in humic acid degradation [45]. Besides this, the expression of $P$. chrysosporium $\mathrm{MnP}$ in $A$. niger has also been reported [46]. LiPs are the most investigated lignolytic enzymes in white-rot fungi, but not in Penicillium $s p$. [47]. LiP has been reported from Aspergillus $s p$. isolated from a mangrove area whose best activity was in coir pith substrate at $3 \%$ concentration [48]. LiP production by Penicillium decumbens has also been reported [49]. Results of our study along with other reports suggest that organisms belonging to these genera are a potential source of lignolytic enzymes and thus can be exploited for production and applications of these industrially significant enzymes. However, further research is required to determine best conditions for maximal production of lignolytic enzymes by these organisms.

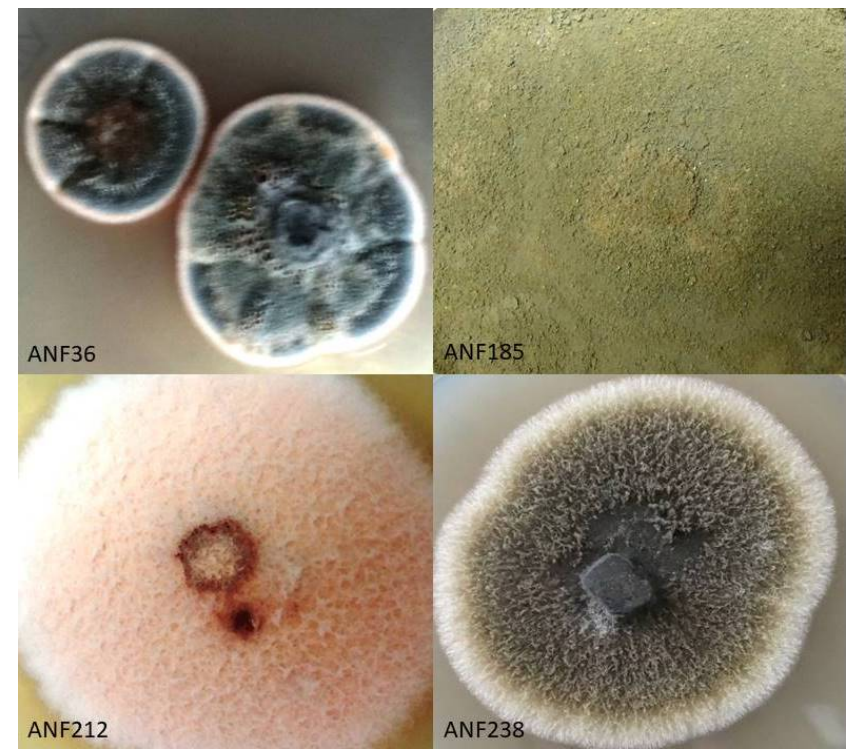

Figure 5. Colony morphology of selected isolates

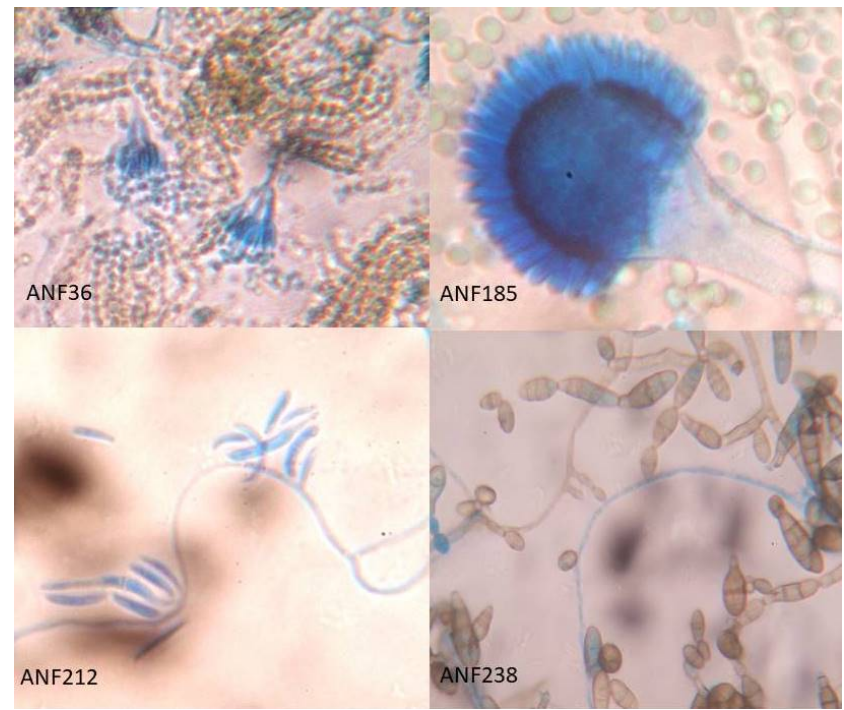

Figure 6. Microscopic view after lactophenol cotton blue staining 
Table 3. Comparative analysis of enzyme activities of selected fungal isolates

\begin{tabular}{|c|c|c|c|c|c|c|c|}
\hline \multirow[b]{2}{*}{ Isolate } & \multirow[b]{2}{*}{$\begin{array}{l}\text { Source of } \\
\text { Isolation }\end{array}$} & \multicolumn{2}{|c|}{ Laccase activity } & \multicolumn{2}{|c|}{ MnP Activity } & \multicolumn{2}{|c|}{ LiP activity } \\
\hline & & $\begin{array}{c}\text { Stationary } \\
\text { Fermentation } \\
(\mathrm{U} / \mathrm{ml})\end{array}$ & $\begin{array}{c}\text { Solid State } \\
\text { Fermentation } \\
(\mathrm{U} / \mathrm{gds})\end{array}$ & $\begin{array}{c}\text { Stationary } \\
\text { Fermentation } \\
(\mathrm{U} / \mathrm{ml})\end{array}$ & $\begin{array}{c}\text { Solid State } \\
\text { Fermentation } \\
(\mathrm{U} / \mathrm{gds})\end{array}$ & $\begin{array}{c}\text { Stationary } \\
\text { Fermentation } \\
(\mathrm{U} / \mathrm{ml})\end{array}$ & $\begin{array}{c}\text { Solid State } \\
\text { Fermentation } \\
(\mathrm{U} / \mathrm{gds})\end{array}$ \\
\hline ANF36 & $\begin{array}{c}\text { Cardboard } \\
\text { industry } \\
\text { wastewater }\end{array}$ & $2.67 \pm .12$ & $15.28 \pm .72$ & $0.186 \pm .021$ & $0.98 \pm .024$ & $0.15 \pm .012$ & $0.47 \pm .02$ \\
\hline ANF185 & $\begin{array}{c}\text { Termite } \\
\text { infested soil }\end{array}$ & $2.66 \pm .18$ & $17.12 \pm .54$ & $0.169 \pm .009$ & $1.25 \pm .012$ & $0.2 \pm .013$ & $0.54 \pm .032$ \\
\hline ANF212 & $\begin{array}{c}\text { Agricultural } \\
\text { soil }\end{array}$ & $2.51 \pm .24$ & $10.32 \pm .75$ & $0.254 \pm .012$ & $1.34 \pm .025$ & $0.19 \pm .02$ & $1.65 \pm .03$ \\
\hline ANF238 & Rotten wood & $3.42 \pm .23$ & $17.85 \pm .92$ & $0.229 \pm .01$ & $1.02 \pm .031$ & $0.22 \pm .021$ & $1.78 \pm .041$ \\
\hline
\end{tabular}

Stationary conditions: Basal medium ( $\mathrm{pH} 5.0$ ) containing $1 \%$ water hyacinth biomass

Solid State Fermentation: $5 \mathrm{~g}$ of dry water hyacinth biomass, $10 \mathrm{ml}$ of basal medium to maintain $200 \%(\mathrm{v} / \mathrm{w})$ Initial moisture content. Incubation at $25 \pm 20^{\circ} \mathrm{C}$ for 10 days

\section{Conclusions}

The present study was undertaken with the aim of isolation and screening of fungi with lignolytic fungi from various environmental sources. Four fungal strains belonging to four different genera exhibited all the three extracellular lignolytic enzymes (Laccase, Manganese peroxidase and Lignin peroxidase) activities. Highest laccase activity was produced by ANF238 $(3.42 \mathrm{U} / \mathrm{ml})$ while highest manganese peroxidase and lignin peroxidase activities were produced by ANF $212(0.254 \mathrm{U} / \mathrm{ml})$ and ANF238 $(0.22 \mathrm{U} / \mathrm{ml})$ respectively. The present work is a preliminary study and further research is required for enhanced production of enzymes by optimization of various cultural and environmental parameters. Therefore, these isolates can be considered promising organisms for enzymes (laccase, MnP and LiP) production and various industrial and biotechnological applications including biodegradation of lignocellulosic biomass for ethanol production.

\section{Conflict of Interests}

The authors declare that there is no conflict of interests regarding the publication of this paper.

\section{REFERENCES}

[1] J. Wang, J. Liu, M. Li and Z. Yin. Isolation Identification and Characteristics of Lignocelluloses Degrading Fungus, Proceedings of the Twentieth International Offshore and Polar Engineering Conference Beijing, China, pp. 20 -25, 2010.

[2] E. Hasan Abd-Elsalam and A. El-Hanafy. Lignin Biodegradation with Ligninolytic Bacterial Strain and Comparison of Bacillus subtilis and Bacillus sp. isolated from Egyptian Soil, American-Eurasian Journal of Agricultural and Environmental Science, vol. 5, pp. 39-44, 2009.

[3] M. Saritha, A. Arora, Lata. Biological Pretreatment of Lignocellulosic Substrates for Enhanced Delignification and
Enzymatic Digestibility, Industrial Journal of Microbiology. Vol. 52, pp. 122-130, 2012.

[4] R. Kumar and A. Kumar. Process for isolation and acclimatization of bacteria for lignin degradation, US 7,022,511 B2, Apr. 4, 2006.

[5] O. Schmidt. Wood and Tree Fungi: Biology, Damage, Protection, and Use, Chapter 3: Physiology and Chapter, 4: Wood cell wall degradation, Springer: Berlin, 2006.

[6] T. Higuchi. Look back over the studies of lignin biochemistry, Journal of Wood Science, vol. 52, pp. 2-8, 2006.

[7] P. Alvira, E. Tomas-Pejo, M. Ballesteros, M.J. Negro. Pretreatment technologies for an efficient bioethanol production process based on enzymatic hydrolysis: a review, Bioresource Technology, vol. 101, pp. 4851-4861, 2010.

[8] S.D. Mansfield, C. Mooney, J.N. Saddler. Substrate and enzyme characteristics that limit cellulose hydrolysis, Biotechnology Progress, vol. 15, pp. 804-816, 1999.

[9] J.M. Taherzadeh, K. Karimi. Pretreatment of lignocellulosic wastes to improve ethanol and biogas production: a review, International Journal of Molecular Science, vol. 9, pp. 1621$1651,2008$.

[10] O. Sanchez and C. A. Cardona. Trends in biotechnological production of fuel ethanol from different feedstocks, Bioresource Technology, vol. 99, pp. 5270 - 5295, 2008.

[11] T. Tassinari, C. Macy, L. Spano. Energy requirements and process design considerations in compression milling pretreatment of cellulosic wastes for enzymatic hydrolysis, Biotechnology and Bioengineering, vol. 22, pp. 1689-1705, 1980.

[12] S. Malherbe and T. E. Cloete. Lignocellulosic biodegradation: fundamentals and applications: a review, Environmental Science and Biotechnology, vol. 1, pp. 105-114, 2003.

[13] V. Singhal and V.S. Rathore. Effects of $\mathrm{Zn}^{2+}$ and $\mathrm{Cu}^{2+}$ on growth, lignin degradation and lignolytic enzymes in Phanerochaete chrysosporium, World Journal of Microbiology and Biotechnology, vol. 17, pp. 235-240, 2001.

[14] J. Baeza, C. Parra, A. Berrocal, S. Perez, J. Rodriguez, J. Freer. Prediction of bioethanol production from soft- and hardwood. In: 229th ACS National Meeting. CELL 126. Washington: ACS, 2005. 
[15] N. Verma, M.C. Bansal, V. Kumar V. Pea peel waste: a lignocellulosic waste and its utility in cellulase production by Trichoderma reesei under solid state cultivation. Bioresources, vol. 6, pp. 1505-1519, 2011.

[16] A. Sharma, N.K. Aggarwal, A. Saini, A. Yadav. Beyond Biocontrol: Water Hyacinth Opportunities and Challenges. Journal of Environmental Science and Technology, vol. 9, no. 1, pp. 26-48, 2016.

[17] M. Tien and T.K. Kirk. Lignin-degrading enzyme from the hymenomycetes Phanerochaete chrysosporium burds, Science, vol. 221, pp. 661-663, 1983.

[18] A. Sharma, N.K. Aggarwal A.Yadav, First Report of Lignin Peroxidase production from Alternaria alternata ANF238 isolated from rotten wood sample, Bioengineering and Bioscience, vol. 4, no. 5, pp. 76-87, 2016.

[19] H. Gao, Y. Wang, W. Zhang, W. Wang, Z. Mu. Isolation, identification and application in lignin degradation of an ascomycete GHJ-4, African Journal of Biotechnology, vol. 10, no. 20, pp. 4166-4174, 2011.

[20] S. Desai, B. Gururaj, Tennali, N. Channur, A.C. Anup, G. Deshpande G, B.P. Azhar Murtuza. Isolation of laccase producing fungi and partial characterization of laccase, Biotechnology Bioinformatics Bioengineering, vol. 1, no. 4, pp. 543-549, 2011.

[21] A. Paszczynski, R.L. Cnawford, V.B. Huynh. Manganese Peroxidase of Phanerochaete chrysosporium: Purification, Methods in enzymology, pp. 264-270, 1988.

[22] F.S. Archibald. A new assay for lignin-type peroxidase employing the dye Azure B, Applied and Environmental Microbiology, vol. 58, pp. 3110-3116, 1992.

[23] V. Elisashvili et al. Lentinus edodes and Pleurotus species lignocellulolytic enzymes activity in submerged and solid-state fermentation of lignocellulosic wastes of different composition, Bioresource Technology, vol. 99, pp. 457-462, 2008

[24] H.K. Kanwal, M.S. Reddy. Effect of carbon, nitrogen sources and inducers on ligninolytic enzyme production by Morchella crassipes, World Journal of Microbiology and Biotechnology, vol. 27 pp. 687-691, 2011.

[25] A. Rodriguez, M.A. Falcon, A. Carnicero, F. Perestelo, G. Fuente, J. Trojanowski. Laccase activities of Penicillium chrysogenum in relation to lignin degradation, Applied Microbiology and Biotechnology, vol. 45, no. 3, pp. 399-403, 1996.

[26] R. Bi, O. Spadiut, M. Lawoko, H. Brumer, G. Henrikson. Isolation and identification of microorganisms from soil able to live on lignin as a carbon source and to produce enzymes which cleave the $\beta-\mathrm{O}-4$ bond in a lignin model compound, Cellulose Chemical Technology, vol. 46, pp. 227-242, 2012.

[27] K.M.G. Machado, D.R. Matheus, V.L.R. Bononi. Ligninolytic enzymes production and Remazol Brilliant Blue $R$ decolorization by tropical Brazilian basidiomycetes fungi, Brazilian Journal of Microbiology, vol. 36, pp. 246-252, 2005.

[28] E. Kalmis, I. Yasa, F. Kalyoncu, B. Pazarbasi, A. Kocyigit. Ligninolytic enzyme activities in mycelium of some wild and commercial mushrooms, African Journal of Biotechnology, vol. 7 , no. 23 , pp. 4314-4320, 2008.
[29] A. Stolz. Basic and applied aspects in the microbial degradation of azo dyes, Applied Microbiology and Biotechnology, vol. 56, pp. 69-80, 2001.

[30] M. Akpinar and R.O. Urek. Production of ligninolytic enzymes by solid state fermentation using Pleurotus eryngii, Preparative Biochemistry and Biotechnology, vol. 42, pp. 582-597, 2012.

[31] D.W.S. Wong. Structure and Action Mechanism of Ligninolytic Enzymes, Applied Biochemistry and Biotechnology, vol. 157, pp. 174-209, 2009.

[32] P. Reanprayoon and W. Pathomsiriwong. Tropical soil fungi producing cellulase and related enzymes in biodegradation, Journal of applied sciences, vol. 12, no. 8, pp. 1909-1916, 2012.

[33] I. Chaudhary, F. Fatima, N. Pathak, S. Rastogi, R. Sharma. Isolation of Lignin Peroxidase producing Plant Pathogenic Fungus from the effluent sample, International journal of advancement in engineering technology, management and applied science, 2015.

[34] N. Sahni and U.G. Phutela. Comparative profile of paddy straw pretreated with standard and isolated lignocellulolytic fungal cultures, Journal of Yeast and Fungal Research, vol. 4, no. 7, pp. 92-97, 2013.

[35] A. Tapwal, S. Varghese, U. Kumar, J. Arora. Production of Laccase by Alternaria alternata and Lasiodiplodia theobromae, European Journal of Experimental Biology, vol. 4, no. 4, pp. 196-201, 2014.

[36] G.K. Tiwari, M. Chittora. Study the effect of various physical and biochemical parameters on the production of laccase enzyme produced from Aspergillus flavus at in vitro conditions, International Journal of Recent Scientific Research, vol. 4 , no. 5 , pp. $662-665,2013$.

[37] R.A. Abd El Monssef, E.A. Hassan, E.M. Ramadan. Production of laccase enzyme for their potential application to decolorize fungal pigments on aging paper and parchment, Anals of Agricultural Science, vol. 61, no. 1, pp. 145-154, 2016.

[38] H.Y. Alfarra, N.H.M. Hasali, M.N. Omar. A Lignolytic fungi with Laccase activity isolated from Malaysian local environment for phytochemical transformation purposes, International Research Journal of Biological Sciences, vol. 2, no. 2, pp. 51-54, 2013.

[39] P.A. Geethanjali. A study on lignin degrading fungi isolated from the litter of evergreen forests of Kodagu (D), Karnataka, International Journal of Environmental Sciences, vol. 2, no. 4, 2012.

[40] U. Sack and T. Gunther. Metabolism of PAH by fungi and correlation with extracellular enzymatic activities, Journal of Basic Microbiology, vol. 33, pp. 269-77, 1993.

[41] M.C.N. Saparrat, M.J. Martinez, H.A. Tournier, M.N. Cabello, A.M. Arambarri. Production of ligninolytic enzymes by Fusarium solani strains isolated from different substrata, World Journal of Microbiology and Biotechnology, vol. 16, pp. 799-803, 2000.

[42] N. Kanayama, T. Suzuki, K. Kawai. Purification and characterization of an alkaline manganese peroxidase from Aspergillus terreus LD-1, Journal of Bioscience and 
Bioengineering, vol. 93, pp. 405-410, 2002.

[43] J.V.B. Souza, E.S. da Silva, F.T. da Silva, T.C.B. Paiva Fungal treatment of a delignification effluent from a nitrocellulose industry, Bioresource Technology, vol. 96, pp. 1936- 1942, 2005.

[44] D.K. Sahoo, R. Gupta. Evaluation of ligninolytic microorganisms for efficient decolorization of a small pulp and paper mill effluent, Process Biochemistry, vol. 40 pp. 1573-1578, 2005.

[45] V. Rezacova, H. Hrselova, H. Gryndlerova, I. Miksik, M. Gryndler. Modifications of degradation-resistant soil organic matter by soil saprobic microfungi, Soil Biology and Biochemistry, vol. 38, pp. 2292-2299, 2006.

[46] A.C.A. Conesa, V.D. Hondel, P.J. Punt. Studies on the production of fungal peroxidases in Aspergillus niger, Applied and Environmental Microbiology, vol. 66, pp. 3016-3023, 2000 .

[47] H.Y. Yu, G.M. Zeng, G.M. Huang, D.L. Huang. Lignin degradation by Penicillium simplicissimum, Huan Jing Ke Xue, vol. 26, no. 2, pp. 167-171, 2005.

[48] S. Ahammed, P. Prema. Influence of media nutrients on synthesis of lignin peroxidase from Aspergillus sp, Applied Biochemistry and Biotechnology, vol. 103, pp. 327-336, 2002.

[49] J.S. Yang, H.L. Yuan, H.X. Wang, W.X. Chen. Purification and characterization of lignin peroxidases from Penicillium decumbens P6, World Journal of Microbiology and Biotechnology, vol. 21, pp. 435-440, 2005. 